\title{
Infodesıgn| Entrevista
}

\section{Gilvania de Melo}

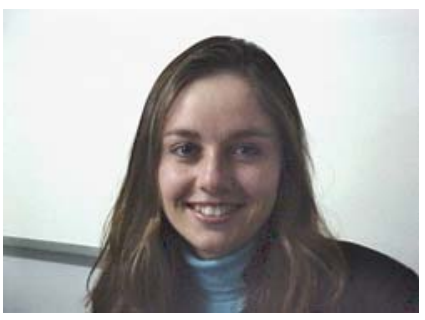

Farmacêutica-Bioquímica formada pela Universidade Estadual da Paraíba

Especialização em Saúde Coletiva na Área de Medicamentos pela Universidade de Brasília

MBA em Planejamento e Gestão Empresarial pela Universidade Católica de Brasília

Mestranda do Programa de Pós-graduação em Gestão do Conhecimento e Tecnologia da Informação da Universidade Católica de Brasília

Trabalhou no desenvolvimento do bulário eletrônico da ANVISA, Ministério da Saúde.

\section{Perguntas}

1. Quando, como e por que você passou a se interessar pelo design de bulas de medicamentos?

Como farmacêutica, tenho constatado que as bulas se constituem naturalmente em uma fonte de informação primária para os usuários de medicamentos senão, a única fonte de informação para alguns após a consulta médica. Então, por enxergar o papel que as bulas podem desempenhar na promoção do uso seguro e racional de medicamentos, voltei os meus estudos na área da gestão do conhecimento para essa temática e no meio destes estudos, tomei conhecimento de alguns trabalhos que têm sido desenvolvidos na área de design de bulas principalmente na UFPR.

2. Você poderia historiar um pouco sua trajetória como pesquisadora, enfatizando projetos relacionados ao design de bulas de medicamentos?

O meu primeiro contato com os textos de bula enquanto material de estudo, ocorreu durante a realização da Especialização em Saúde Coletiva na Universidade de Brasília - UnB. Na época realizei uma pesquisa juntamente com outra colega farmacêutica onde avaliamos a adequabilidade das bulas de medicamentos essências segundo a legislação vigente na época. Pouco tempo depois fui trabalhar na área de registro de medicamentos da Agência Nacional de Vigilância Sanitária - ANVISA onde a análise dos textos de bula fazia parte das nossas atividades diárias. Alguns anos mais tarde a ANVISA decidiu revisar toda a legislação relativa a medicamentos, inclusive a legislação referente às bulas e, em função do trabalho que eu havia realizado na UnB, fui convidada à integrar esta equipe. O resultado deste trabalho deu origem a Resolução RDC no. 140/03 (que é a legislação sobre bulas vigente no momento), ao Sistema de Gerenciamento Eletrônico de Bulas (conhecido como e-Bulas), ao Bulário Eletrônico da ANVISA e ao Compêndio de Bulas de Medicamentos - CBM.

\section{Você teve participação efetiva na criação do Bulário Eletrônico da Anvisa.} Poderia explicar os objetivos e alcance desse projeto?

Durante o processo de revisão da legislação sobre bulas - processo este que posteriormente deu origem a Resolução RDC no. 140/2003 - a ANVISA desenvolveu, em parceria com o Centro Latino-Americano e do Caribe de Informações em Ciências da Saúde - BIREME, o 


\section{Infodesıgn}

Sistema de Gerenciamento Eletrônico de Bulas, mais conhecido como E-Bulas. Por meio desta ferramenta de comunicação entre a ANVISA e a indústria farmacêutica, todo o processo de recepção, distribuição, análise e publicação dos textos de bula deixou de ser realizado em papel passando a ser realizado de forma totalmente eletrônica. Uma vez que todas as bulas dos medicamentos registrados no Brasil estariam, gradativamente, em uma base eletrônica criou-se uma face externa para o e-Bulas, que foi batizado de Bulário Eletrônico. Sem perder de vista a questão do uso racional de medicamentos, além dos textos de bula nas versões para o paciente e para o profissional de saúde, o Bulário trazia também outras matérias relacionadas a saúde, alertas, notícias, links de interesse dentre outros conteúdos. O Bulário era bastante acessado e tinha muitas possibilidades e recursos vinculados a ele chegando inclusive a despertar interesse de outros países da América Latina. Não são poucas as vezes que encontro com pessoas que ao mesmo tempo em que parabenizam pela iniciativa de criação do Bulário, lamentam que ele tenha sido retirada do ar. Isso realmente é uma pena porque a consolidação desse banco de dados eletrônico de bulas, poderia, certamente, resolver ou minimizar muito o "gap" (espaço) de tempo existente entre o momento em que a autoridade sanitária atualiza um texto de bula e o tempo em que efetivamente esta nova informação atualizada chega as mãos dos usuários de medicamentos.

4. Quais são seus interesses de pesquisa, projetos em que esteja envolvida atualmente?

No momento, estou totalmente dedicada a conclusão do Mestrado em Gestão do Conhecimento e da Tecnologia da Informação (em andamento na Universidade Católica de Brasília), onde tenho estudado os textos de bula sob o enfoque da Teoria da Complexidade, na perspectiva da gestão social do conhecimento.

5. Recentemente, tem havido uma série de iniciativas governamentais no sentido de melhorar a qualidade das bulas de medicamentos. Resoluções, disponibilização de material online... você poderia comentar um pouco sobre essas diferentes ações e seus principais efeitos? Já se observa alguma modificação relevante?

As bulas desempenham um papel muito importante enquanto instrumento para o compartilhamento de informações sobre medicamentos logo, iniciativas para implementação de melhorias são, a princípio, bem vindas. Digo a princípio porque, na minha opinião, se essa melhoria não for fruto de um trabalho técnico interdisciplinar bem fundamentado, que leve em consideração as diferentes necessidades e peculiaridades dos públicos-alvo (receptor) e, principalmente, que englobe processos permanentes de avaliação e readaptação, talvez esta não seja de fato uma melhoria. Não estou dizendo que isto não esteja sendo feito por quem de direito, mas quando recordamos o conjunto de ações e iniciativas propostas no então entitulado "Projeto Bulas" a poucos anos atrás e comparamos com o cenário que vemos hoje (E-Bulas retirado da Web; Bulário retirado da Web; não publicação da $2^{a}$. edição do Compêndio de Bulas de Medicamentos conforme previsto na Resolução RDC no. 140/03 e a não harmonização entre os conteúdos dos medicamentos de referência com seus genéricos e similares), ficamos, enquanto estudiosa do assunto, preocupada com a descontinuidade destas iniciativas e com seus possíveis efeitos junto aos usuários de medicamentos, aos profissionais de saúde e a indústria farmacêutica.

6. Observamos que tem havido um aumento progressivo na quantidade de pesquisas relacionadas a bulas de medicamentos, tanto na área de saúde (mais direcionados ao conteúdo), quanto de design da informação (mais direcionadas à apresentação gráfica das informações). Como você considera que essas pesquisas podem contribuir para a melhoria das bulas de medicamentos?

A área da saúde, assim como tantos outros setores da sociedade, está inserida em uma realidade complexa e os textos de bula, por sua vez, também fazem parte desta mesma realidade. Diante disso é necessário que as bulas sejam abordadas sob uma perspectiva não disciplinar uma vez que este tipo de abordagem tem demonstrado não ser suficiente para 


\section{Infodesıgn}

compreender, analisar e lidar com a problemática que envolve as bulas. É importante que pesquisas sejam realizadas pelas mais diversas áreas do conhecimento (até mesmo porque se compararmos a nossa produção científica relacionada a bulas com a produção de outros países, veremos que podemos fazer muito mais do que temos feito) mas o mais importante é que esses conhecimentos saiam das universidades e sejam utilizados na prática por quem produz e legisla sobre textos de bula numa perspectiva interdisciplinar.

\section{Por fim, o que você gostaria de dizer aos leitores da InfoDesign como fechamento em nossa entrevista?}

Primeiramente gostaria de agradecer pela oportunidade de compartilhar conhecimento que me foi concedida pelos responsáveis da InfoDesign e dizer a todos que desenvolvem pesquisas com textos de bula que prossigam e persistam em seus estudos para que um dia, tenhamos de fato um instrumento que tenha valor e sentido para quem dele necessitar fazer uso e que contribua para a promoção do uso seguro e racional de medicamentos. 